\title{
The Mediating Role of the Capital Structure, Growth Rate, and Dividend Policy in the Relationship Between Return on Equity and Market to Book Value
}

\author{
Farouq Altahtamouni ${ }^{1}$, Reem Matahen ${ }^{2} \&$ Amna Qazaq $^{1}$ \\ ${ }^{1}$ Financial Sciences Dept., Community College, Imam Abdulrahman Bin Faisal University, Dammam, Saudi Arabia \\ ${ }^{2}$ Administrative Sciences Dept., Community College, Imam Abdulrahman Bin Faisal University, Dammam, Saudi \\ Arabia \\ Correspondence: Dr. Farouq Altahtamouni, Financial Sciences Dept., Community College, Imam Abdulrahman Bin \\ Faisal University, P.O. Box 1982, Dammam, Saudi Arabia. Tel: 96-65-9989-2978.
}

Received: February 29, 2020

Accepted: March 30, 2020

Online Published: June 28, 2020

doi:10.5430/ijfr.v11n4p155

URL: https://doi.org/10.5430/ijfr.v11n4p155

\begin{abstract}
This Study aims to study the indirect effect of profits measured by the return on stockholders' equity for the Jordanian Banks on market value measured by market value to book value for the period from 2008 to 2017. We have applied the indirect impact model to know the ability of capital structure, growth rate and dividend policy as mediating variables to transfer the impact of profits to market value. By using the simple linear analysis and applying indirect effect test model by using the Sobel equation the study reached out to a positive effect of profits on market value with the presence of debt ratio, growth rate and dividend policy as a mediating variables of that relation.
\end{abstract}

Keywords: return on equity, market value, indirect effect, capital structure, growth rate, dividend policy

\section{Introduction}

Over the past years many researchers have worked on searching in the relation between the accounting profits and market value of companies by examining that relation using many measures of profits and market value.

Since (Ball \& Brown, 1968) studied the relation between accounting profits and market value for stocks throughout the stocks' returns and reached an explanatory power drop in the relation between profits and market value wherein the explanatory power of the test models did not exceed $10 \%$, and that is what the study of (Lev, 1989) have reached also, where they concentrated on making that relation a huge domain to study which was followed by many of researchers to restudy from various aspects using various measurements regarding the parties that are involved, and it was a must to work on the restudy by the researchers to study that relation using a new model hoping to find out new results.

The accounting profits have an important informational content that reflects those financial decisions taken by the decision maker in the firm and those information can be reflected in market if the investors in the financial market could invest those information and reflect it on the market value for the financial security.

Profits analysis is an important element to stockholders, so profits mean the earned income from dividends (Gibson, 1992), therefore according to the previous studies the dividends must be reflected on the market value of the financial securities that are being traded among the investors who work on determining the market value by reading the future and what information may be included that could be useful for their investment.

Thus, we come to a conclusion that there must be a relation between the stock's price and the realized profit in the company which owns the stock, so if the company achieved a magnificent profits, these profits will be added to the shareholders equity in the company which is supposedto raise the stock's price and vice versa, and also this is the logical and realistic explanation to calculate the price value for any stock, and when talking about the stock's price in the stock market we may often find a huge and illogical variation between the market price and the company's profit, in some cases for example, we may findthat a company's profits has dropped remarkably or has gained a loss, except we find that its stock's price rising, and the logical explanation due to many and divided factors that are not related to its profits neither their loss, that is why these factors play an essential role in raising or lowering the stock's price, 
and the investors have expectations about achieving a huge future profits that would raise the market stock's value simultaneously.

(Gitman, 2000) has clarified the difference between the goal of profit maximization and the owners' wealth maximization and the relation between profitability and market value of stocks and he said that profit maximization is not the preferred goal by owners and the firm'smanagement due to many reasons including that the accounting profit does not necessarily result a monetary flows available for shareholders, and the monetary flows come from two sources: the profits dividends and capital profits, furthermore, rising the return of a single stock (EPS) does not necessarily lead to a raise in profits dividends nor translated to a raise in market stock's price.

As (Al-Debi'e \& Abu-nassar, 2001) and (Al-Debi'e \& Alzahrani, 2016) have pointed out that the relation of accounting profits must be measured by market value for stocks asynchronously, so if we measured that relation simultaneously then the relation will be weak, and when the company grows as a result of making a specific financial decision then that growth will be reflected on the future value of financial security on a basis of it is a result of reflecting what will happen in the future and that is what will be reflected on the accounting profits when it happens and does not reflect on the historical accounting profits because the timing acknowledgement process of the economic event does not usually match with the time of happening the economic event.

The growth in future profits dividends came from the current profits retention decision and reinvest that profits to reach a future growth that has all the importance in defining the market value, so as (Corrado, Jordan, 2005) pointed out that there are many ways to estimate the future growth of dividends in the stable growth dividends model including the continuous growth rate that contains using the firm return to estimate the growth in dividends, which confirms that the growth in dividends is a reflection of growth in the return.

So we have developed the scientific idea for the theoretical basis of research and working on develop a model to study the profits effect on the market value simultaneously by applying the model of indirect effect for profits on the market value through out many mediating variables. The first model is based on the capital structure as mediating variable measured by the debt ratio to the owner's equity considering that the current profits are an important factor in determining the financial decision according to Pecking Order Theory (Myers 1984), and that decision is what the current market value of the financial security will be built on. The second mode is based on the growth in divided profits. The third model is based on the dividend policy, where (Gordon, 1963) stressed the existence of a relationship between the distribution of cash profits and the market value of companies. Where the accounting profits of the current financial year does not affect directly on the market value of the stock in the same period but the change in the market value is the profits effect reflection on the mediating variables and then the reflection of that variables on the market value.

\section{The Study Goals}

This study aims to:

1) Measuring the realized profits effect on capital structure.

2) Measuring the realized profits effect on the growth.

3) Measuring the realized profits effect on dividend policy.

4) Measuring the capital structure effect, growth and dividend policy on the market value.

5) Measuring the indirect effect of profits on the market value.

\section{Importance of the Study}

The importance of the study comes from the importance of the relation between profits and company value, and the consequence effect of the financial policies on that relation, the importance of the study also comes from depending on the previous studies that have discussed this topic starting with (Modigliani \&Miller $\{$ M\&M 1 1963) study and (Gordon, 1963).

The study importance comes also from being the first study according to researchers science which is based on studying the indirect effect of realized profits on the market value throughout capital structure, the growth rate in profits and dividend policy as a mediating variable in that relation by applying on Jordanian Banks.

\section{The Study Problem}

The study problem can be formulated throughout the following questions as the general frame of this study and the base which was relayed on to build the study model: 
- Are the realized profits at the end of the financial year affect the investors' expectations in the financial market, hence, the realized profits will be reflected either positively or negatively on the current market value? Or else as the market value is an expectation of future monetary flows, are the currently realized profits reflect directly in the realized market value at the end of the financial year?

-There are some companies that gain a drop in their profits, nonetheless, it works on distributing cash profits from the retained profits earlier on the shareholders to keep its market value, hence, is the raise in the market value coming from profits dividends is a real reflection for the drop in the profits? This concludes that the market value is not defined according to the realized profits but on what comes from those profits whether its dividends or retained profits.

\section{Literature Review}

- (Pandey, 2005): This study empirically explores the significance of profitability and growth as drivers of shareholder value, measured by the market-to-book value $(\mathrm{M} / \mathrm{B})$ ratio. The study findings show a strong positive relationship between economic profitability and $\mathrm{M} / \mathrm{B}$ ratio. Growth, on the other hand, is negatively related to $\mathrm{M} / \mathrm{B}$ ratio. However, the economic profitability-growth interaction variable has a positive coefficient indicating that growth associated with economic profitability influences shareholder value positively.

- (Zeitun\&Tian, 2007): This study aim is to investigate the effect which capital structure has had on different measures of corporate performance. The results showed that a firm's capital structure had a significantly negative impact on the firm's performance measures, in both the accounting and market's measures and also found that the short-term debt to total assets (STDTA) level has a significantly positive effect on the market performance measure (Tobin's Q).

- (John \&Muthusamy, 2010): The researchers tried to find the relation between profits dividends and a couple of variables including the profitability measured by the return of one share and the return on assets, and they found an inverse relation between the profits and the rate of divided profits which measuring the profits dividends policy.

- (Chen \& Chen, 2011): This study focused on the relationships between these three variables. This research investigated whether leverage is a mediating variable for profitability and corporate performance. In addition, with the aid of two regressions, this work examined if the moderating variables are type and size, as well as the relationships among the three variables, as mentioned above. The results confirmed that profitability has a positive effect on firm value, and a negative effect on the leverage, while the leverage has a negative effect on the value, and profitability has a significant mediating effect. When investors consider the influence of profitability on firm value, they cannot ignore the leverage's negative effect on the firm value, because a high level of debt may cancel the positive effect of profitability on firm value.

- (OGBULU \& EMENI, 2012): This study seeks to provide evidence on the impact of capital structure on a firm's value. The result of the study reveals that in an emerging economy like Nigeria, equity capital as a component of capital structure is irrelevant to the value of a firm, while Long-term-debt was found to be the major determinant of a firm's value.

- (Rehman\& Takumi, 2012): This study examines the determinants of dividend payout ratio in the largest stock exchange of Pakistan i.e. Karachi Stock Exchange (KSE). Relation of debt to equity ratio, profitability, current ratio and corporate tax was found to be positive with dividend payout ratio while Operating cash flow per share and market to book value ratio has a negative relationship with dividend payout ratio. Profitability, debt to equity and market to book value ratios were found to be the significant determinants of dividend payout ratio in Pakistan.

- (Hermuningsih, 2013): This paper examines the influence of profitability, growth opportunity, and capital structure on firm value. The result shows that profitability, growth opportunity and capital structure positively and significantly affect the company's value. Secondly, the capital structure intervene the effect of growth profitability on company's value, but not for profitability.

- (Altahtamouni, Alslehat, 2014): This study aims to investigate the impact of accounting indicators which are the return on assets, return on equity and earnings per share in addition to growth which is measured by sustainable growth rate on the market value which is measured by market share price, stock return and by market value to book value. The results showed that all current accounting indicators and the current growth have a positive impact on the market share price and the market value to book value, and there is no effect of the current accounting indicators and the current growth on the stock market return. 
- (Matthew et. al., 2014): This study examines the effect of dividend payment on the market price of shares of firms on the Nigeria Stock Exchange (NSE). The study seems to be a confirmatory test of dividend relevance or irrelevance as propounded by the various schools of thought. The result shows that there is a positive relationship between dividend payment and market share prices. Secondly, the study provides evidence of the aggregate effect of dividend payment on share prices. The result confirms that the impact of dividend payout on share prices is insignificant which is in line with the irrelevance theory of Modigliani and Miller (1961). Thirdly, the result confirms that there are some other exogenous and endogenous variables other than dividend payout that are responsible for the movement of share prices on the NSE.

- (Kontesa, 2015): The purpose of this study was conducted to examine the relationship between capital structure, the company's performance (ROE) and Firm value (Tobin's Q) of companies listed on the Indonesian Stock Exchange. Results showed that the financial performance be a better mediator to firm value than the capital structure. There is a negative influence between capital structure and profitability, the positive effects of capital structure and profitability of the Firm's value.

- (Khan et. al., 2017): This research probes the determinants that affect the dividend policy of Pakistani Manufacturing firms that are listed on Karachi Stock Exchange (KSE). This research found that profitability has a significant relationship with dividend payout ratio.

- (Purwohandoko, 2017): This study aims to examine the effect of size, growth, and profitability on corporate value with capital structure as a mediator. The results of this study indicate that firm size and firm growth have no effect on capital structure. Profitability negatively affects the capital structure.

- (Tamrin et. al., 2017): This study aims to analyze the effect of Profitability and Corporate Governance Structure on dividend policy and its impact on the firm value. The results showed profitability is a negative significant effect on dividend policy (direct). Profitability has a positive and significant effect on firm value (direct). Profitability have a negative and insignificant effect on firm value as a mediated of dividend policy (indirect effect). Corporate governance structure has a positive and significant effect on dividend policy (direct). Corporate governance structure has a positive and significant effect on firm value. Corporate governance structure is a positive and significant effect on firm value as a mediated dividend policy (indirect).

- (Gunawan, 2018): The purpose of this study is to test the possibility of firm to pay dividends based on the explanatory variables: and investment opportunity, profitability, liquidity and know the accuracy rate of grouping firms that pay dividends and that do not pay dividends based on these explanatory variables. This study concludes two things. Firstly, there is a positive effect of investment opportunity, profitability and liquidity on possibility of firm to pay dividends. Secondly, the accuracy rate of grouping firms into the group of firms paying dividends and firms that do not pay dividends based on the ability of explanatory variables is $87.1 \%$.

After doing a research in the previous studies, the researchers did not find a single study discussing the indirect effect of profits on the market value throughout capital structure and growth by applying on the Jordanian Banks, accordingly, the idea of the study came from considering that the market value is an affected value by the companies policies that affected by the profits, so that relation had to be studied to present a new model complementing the previous studies.

\section{Methodology of the Study}

\subsection{Community and Sample of the Study}

The community of the study consists of the Jordanian Banks working in the Jordanian financial sector from 2008 until 2017, but the study sample (15) banks have been chosen out of (16) according to the presence of the data serving the study.

\subsection{Hypotheses of the Study}

The study hypotheses were formulated based on the study goals and the study problem to examine the indirect effect of profits on the stocks market value, accordingly the study hypotheses were formulated as following:

- H01: No statistical significant effect of profits on the market value throughout capital structure as a mediate variable.

H01.1: No statistical significant effect of profits on capital structure.

H01.2: No statistical significant effect of capital structure on the market value. 
- H02: No statistical significant effect of profits on the market value throughout the growth rate a mediate variable.

H02.1: No statistical significant effect of profits on the growth rate.

H02.2: No statistical significant effect of growth on the market value.

- H03: No statistical significant effect of profits on the market value throughout the dividend policy as a mediate variable.

H03.1: No statistical significant effect of profits on the dividend policy.

H03.2: No statistical significant effect of dividend policy on the market value.

\subsection{The Study Variables}

The following variables will be used to serve the study purposes:

\subsubsection{Independent Variable (IV)}

- $\quad$ Return on stockholder equity $(\mathrm{ROE})=$ Net profit / Stockholder equity (Kontesa, 2015), (Altahtamouni, Alslehat, 2014).

\subsubsection{Mediating Variables (MV)}

- $\quad$ Capital Structure $=$ Total liabilities / Stockholder equity (Kontesa, 2015).

- $\quad$ Growth rate $=$ The return on stockholder equity $\times$ Retention ratio (Pandey, 2005), (Altahtamouni, Alslehat, 2014).

- $\quad$ Dividend policy measured by dividend per share = Dividends paid / \# of shares outstanding (Matthew et. al., 2014)

6.3.3 Dependent Variable (DV)

- $\quad$ Market value to Book value of stock = Market value of a single stock / Book value of a single stock (Pandey, 2005), (Zeitun, Tian, 2007).

\subsection{Statistical Methods and Models Used in the Study}

The simple linear regression examination will be used by ordinary least squares method (OLS) and by using Panel Data to examine hypotheses of the study according to the following models:

(1) $C S=\alpha 0+\beta 1 R O E+e i$

Whereas:

CS: Capital structure

ROE: Return on Equity

ei: Error indicator

(2) $G R=\alpha 0+\beta 1 R O E+e i$

Whereas:

GR: Growth in dividend

(3) $D P S=\alpha 0+\beta 1 R O E+e i$

Whereas:

DPS: dividend per share

(4) $M B=\alpha 0+\beta 1 C S+e i$

(5) $M B=\alpha 0+\beta 1 G R+e i$

(6) $M B=\alpha 0+\beta 1 D P S+e i$

Whereas:

MB: Market value to Book value

Throughout those equations the profitability effect will be studied on the market value by multiplying profitability coefficient in the first, second and third equation by capital structure coefficient, the growth rate coefficient and the dividend coefficient in the fourth, fifth and sixth equation. 
- $b$ indirect $=(a)(b)$ (Mackinnon\& Dwyer 1993)

Whereas $b$ indirect is the indirect affection coefficient of independent variable on the dependent variable, then we work on examining the indirect affection indication of independent variable on the dependent variable by examining ( $\mathrm{T}$ test) and by applying the following equation:

\section{$T$ indirect $=b$ indirect $/ S b$ indirect}

Whereas (Sb indirect) is the standard error of indirect affection coefficient, and the coefficient is extracted by the following equation (Sobel 1982):

$$
s_{b}=\sqrt{b^{2} s_{a}^{2}+a^{2} s_{b}^{2}}
$$

Whereas:

b: mediate variable coefficient

a: independent variable coefficient

$\mathrm{Sb}$ : standard error of mediate variable

Sa: standard error of independent variable

6.5 Study Models

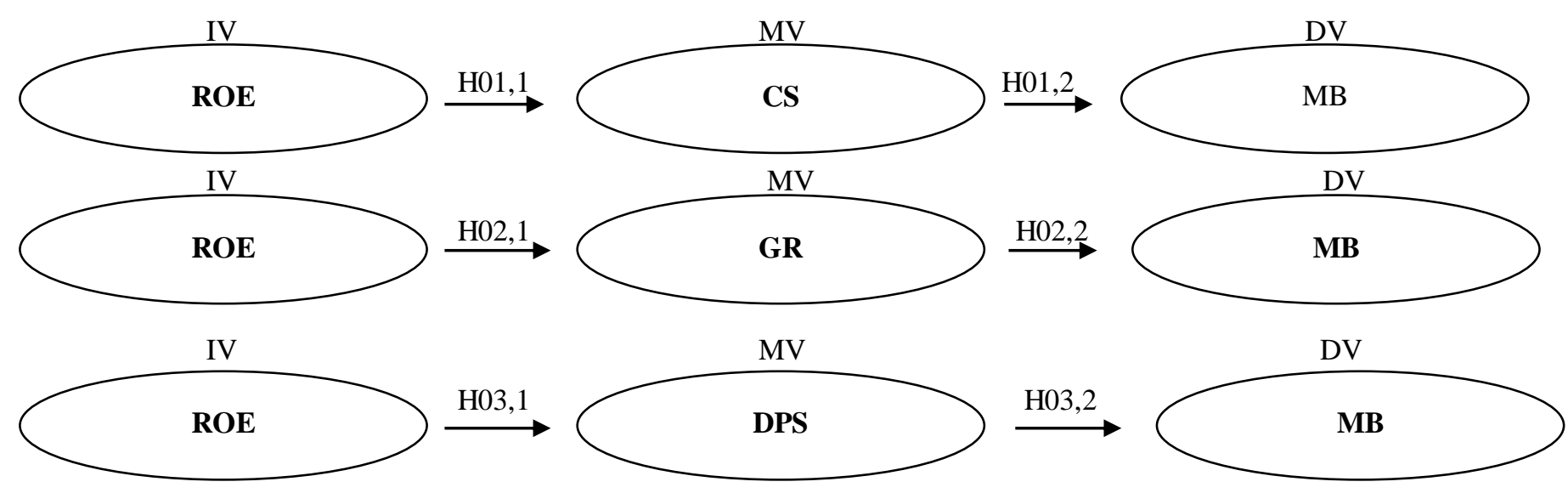

The study models are based on searching the causing series, whereas the methodology which uses the mediate variable (MV) aims to knowing the causing series and how to transfer the effect from one variable to another, the mediate variable in the model works on transferring the relation from independent variable (IV) to dependent variable (DV)throughout it, so the goal of the model is knowing how every variable caused the change happened in the other variable and transferring that to the next variable, (MacKinnon\& Dwyer 1993).

\section{Results of the Study Examinations}

Before analyzing the indirect impact of profit on market value, it is necessary to ascertain the direct impact of profit on market value. Where table No.1 indicates there is a significance effect for profitability on market value.

\subsection{Profits Effect on the Market Value Throughout Capital Structure as a Mediate Variable}

\subsubsection{Profits Effect on Capital Structure}

Table 1 clarifies the profits effect on capital structure, where it is clear that the relation among the variables is a direct relation and there is a statistical significant positive effect of profits on capital structure and this result agrees with Tradeoff theory, and as was mentioned in (Santu, 2018) study whereas the companies with high profitability always prefer to use the debt as ratio from capital structure, accordingly we except the presence of statistical significant effect hypothesis of profits on capital structure. 
Table 1. Result of effect of profits on capital structure

\begin{tabular}{lll}
\hline Variable & Equation results & Hypothesis testing \\
\hline ROE & $.685^{*}$ & \\
\cline { 1 - 2 } Std.Error & .129 & \\
\cline { 1 - 1 } H & .400 & \\
\hline R-Square & .160 & Rejected \\
\hline
\end{tabular}

* Denotes $1 \%$ level of significance

\subsubsection{Capital Structure Effect on the Market Value}

Table 2 clarifies capital structure effect on the market value, and we find a statistical significant positive effect of capital structure on the market value, and this result agrees with (M\&M, 1963) theory.

Table 2. Result of effect of capital structure on market value

\begin{tabular}{lll}
\hline Variable & Equation results & Hypothesis testing \\
\hline CS & $1.686^{*}$ & \\
\hline Std.Error & .502 & H01,2: Rejected \\
\hline R & .266 & \\
\hline R-Square & .071 &
\end{tabular}

* Denotes $1 \%$ level of significance

\subsubsection{The Indirect Effect of Profits on the Market Value}

Table 3 clarifies the indirect effect of profits on the market value throughout capital structure where there is a positive statistical significant effect of profits on market value, and that result supports the idea of capital structure ability to transfer the profits effect to the market value throughout it as mediate variable.

Table 3. Result of indirect effect of profits on the market value throughout capital structure as a mediate variable

\begin{tabular}{lllll}
\hline Variable & Coefficients of indirect effect & T & $p$-value & Hypothesis testing \\
\hline ROE & 1.1549 & 2.8384 & 0.004 & H01: Rejected \\
\hline
\end{tabular}

\subsection{Profits Effect on the Market Value Throughout Growth Rate as Mediate Variable}

7.2.1 Profits Effect on the Growth Rate

Table 4 clarifies profits effect on the growth rate, where it turns out the following:

Table 4. Result of effect of profits on growth rate

\begin{tabular}{|c|c|c|}
\hline Variable & Equation Results & Hypothesis Testing \\
\hline ROE & $.546^{*}$ & \\
\hline Std.Error & .045 & \\
\hline $\mathrm{R}$ & .703 & H02,1 Rejected \\
\hline R-Square & .495 & \\
\hline
\end{tabular}

* Denotes $1 \%$ level of significance 


\subsubsection{Growth Rate Effect on the Market Value}

Table 5 clarifies growth rate effect on the market value, where we can find a positive statistical significant effect of growth rate on the market value as was mentioned in (Altahtamouni, Alslehat, 2014).

Table 5. Result of effect of growth on market value

\begin{tabular}{lll}
\hline Variable & Equation Results & Hypothesis Testing \\
\hline GR & $3.403^{*}$ & \\
\hline Std. Error & 1.114 & H02,2 Rejected \\
\hline R & .243 &
\end{tabular}

* Denotes $1 \%$ level of significance

\subsubsection{The Indirect Effect of Profits on the Market Value}

Table 6 clarifies the indirect effect of profits on the market value throughout the growth rate, where we find a positive statistical significant effect of profits on the market value, and that result supports the idea of the growth rate ability in future dividends on transferring profits effect to the market value throughout it as a mediate variable.

Table 6. Result of indirect effect of profits on the market value throughout growth rate as a mediate variable

\begin{tabular}{lllll}
\hline Variable & Coefficients of Indirect Effect & $\mathrm{T}$ & $p$-value & Hypothesis Testing \\
\hline ROE & 1.8580 & 2.9623 & 0.003 & H02: Rejected \\
\hline
\end{tabular}

\subsection{Profits Effect on the Market Value Throughout Dividend Policy as a Mediate Variable}

\subsubsection{Profits Effect on the Dividend Policy}

Table 7 clarifies profits effect on the dividend policy, where it turns out the following:

Table 7. Result of effect of profits on dividend policy

\begin{tabular}{|c|c|c|}
\hline Variable & Equation Results & Hypothesis Testing \\
\hline ROE & $.855^{*}$ & \\
\hline Std.Error & .158 & \\
\hline $\mathrm{R}$ & .407 & H03,1 Rejected \\
\hline R-Square & .165 & \\
\hline
\end{tabular}

* Denotes $1 \%$ level of significance

\subsubsection{Dividend Policy Effect on the Market Value}

Table 8 clarifies dividend policy effect on the market value, where we can find a positive statistical significant effect of dividend on the market value as was mentioned in (Gordon 1963) and (Matthew et. al., 2014).

Table 8. Result of effect of dividend policy on market value

\begin{tabular}{lll}
\hline Variable & Equation Results & Hypothesis Testing \\
\hline DPS & $2.735^{*}$ & \\
\hline Std. Error & .360 & H03,2 Rejected \\
\hline R & .530 &
\end{tabular}




R-Square $\quad .280$

* Denotes $1 \%$ level of significance

7.3.3 The Indirect Effect of Profits on the Market Value

Table 9 clarifies the indirect effect of profits on the market value throughout the dividend policy, where we find a positive statistical significant effect of profits on the market value, and that result supports the idea of the dividend policy ability in future dividends on transferring profits effect to the market value throughout it as a mediate variable.

Table 9. Result of indirect effect of profits on the market value throughout dividend policy as mediate variable

\begin{tabular}{lllll}
\hline Variable & Coefficients of Indirect Effect & $\mathrm{T}$ & $p$-value & Hypothesis Testing \\
\hline ROE & 2.3384 & 4.4075 & 0.0000 & H03: Rejected \\
\hline
\end{tabular}

\section{Conclusions}

We conclude from the results of indirect effect model which is applied on the Jordanian banks from 2008-2017 ability of the capital structure, the growth rate and dividend policy as the mediating variables on transferring the profits effect to market value, hence, the realized profits have an indirect effect on the market value, and that relation is affected by the companies' decisions related with mixing capital structure and profits dividends policies where it affect positively on transferring that effect. Where the higher the profits of Jordanian banks, the greater their dependence on debt and thus increased market value affected by the increase in debt in the capital structure, and the higher the profits, the higher the growth in the expected profit distribution and the higher the cash dividend, therefore the value of the Jordanian banks is affected by the expected growth of profits distributed in the future and the cash distribution.

\section{References}

Al-Debi'e, M., \& Abu Nassar, M. (2001). Do Share Prices Lead Earnings in Reflecting Value-Relevant Information?. Journal of Dirasat, 28(1), 54-67. Retrieved from https://www.researchgate.net/publication/284029924

Al-Debi'e, M., \& Alzahrani, A. (2016). Suggested Methodologies to Improve The Return- Earnings Relationship. Jordan Journal of Business Administration, 12(2), 271-288. https://doi.org/10.12816/0033350

Altahtamouni, F., \& Alslehat, Z. (2014). The impact of accounting indicators and growth on the market value. International Journal of Academic Research in Accounting, Finance and Management Sciences, 4(2), 9-18. http://doi.org/10.6007/IJARAFMS/v4-i2/725

Ball, R., \& Brown, P. (1968). An Empirical Evaluation of Accounting Income Numbers. Journal of Accounting Research, 6(2), Autumn, 159-178. https://doi.org/10.2307/2490232

Chen, L., \& Chen, S. (2011). The influence of profitability on firm value with capital structure as the mediator and firm size and industry as moderators. Investment Management and Financial Innovations, 8(3). Retrieved from https://businessperspectives.org/author/li-ju-chen

Corrado, C. J., \& Jordan, B. D. (2005). Fundamental of Investment Valuation \& Management (3rd ed.). McGraw-Hill.

Gibson, C. H. (1992). Financial Statement Analysis (5th ed.). South- Western Publishing Co.

Gitman, L. J. (2000). Managerial Finance (9th ed.). Addison Wesley Publishing Company.

Gordon, M. J. (1963). Optimal Investment and Financing Policy. Journal of Finance, 18, 264-272. https://doi.org/10.1111/j.1540-6261.1963.tb00722.x

Gunawan, F, S. (2018). The Effect of Profitability, Liquidity and Investment Opportunities on Dividend Policy. South East Asian Journal of Contemporary Business, Economics and Law, 15(5), 189-195. Retrieved from http://seajbel.com/wp-content/uploads/2018/06/seajbel-238.pdf

Hermuningsih, S. (2013). Profitability, Growth Opportunity, Capital Structure and the Firm Value. Buletin Ekonomi Moneter Dan Perbankan, 16(2), 115-136. http://doi.org/10.21098/bemp.v16i2.440 
John, S. F., \& Muthusamy, K. (2010). Leverage, Growth and Profitability as Determinants of Dividend Payout Ratio-Evidence from Indian Paper Industry. Asian Journal of Business Management Studies, 1(1), 26-30. Retrieved from https://www.idosijournals.org/ajbms/ajbms1(1)10.htm

Khan, R., Meer, J, K., Lodhi, R. N., \& Aftab, F. (2017). Determinants of Dividend Payout Ratio: A Study of Kse Manufacturing Firms in Pakistan. Journal of Business Studies, 13(1), 12-24. Retrieved from http://ibt.edu.pk/ojss/index.php/jbs/article/view/14

Kontesa, M. (2015). Capital Structure, Profitability, and Firm Value. Whats New?. Research Journal of Finance and Accounting, 6(20), 185-192. Retrieved from https://www.iiste.org/Journals/index.php/RJFA/article/view/26331

Lev, B. (1989). On the Usefulness of Earning: Lessons and Directions from two Decades of Empirical Research. Journal of Accounting Research, 27, 129-153. https://doi.org/10.2307/2491070

MacKinnon, D. P., \& Dwyer, J. H. (1993). Estimating Mediated effects in Prevention Studies. Evaluation Review, 17(2), 144-158. http://doi.org/10.1177/0193841x9301700202

Matthew, O. M., Enekwe, C. I., \& Anyanwaokoro, M. (2014). Effect of Dividend Payment on the Market Price of Shares: A Study of Quoted Firms in Nigeria. Journal of Economics and Finance, 5(4), 49-62. http://doi.org/10.9790/5933-0544962

Miller, M. H., \& Modigliani, F. (1961). Dividend Policy, Growth, and the Valuation of Shares. The Journal of Business, 34(4), 411-433. https://doi.org/10.1086/294442

Modigliani, F., \& Miller, M. (1963). Corporate Income Taxes and the Cost of Capital: Acorrection. American Economic Review, 53, 433-443. $\quad$ Retrieved from https://www2.bc.edu/thomaschemmanur/phdfincorp/MF891\%20papers/MM1963.pdf

Myers, S. (1984). The Capital Structure Puzzle. Journal of Finance, 39(3), 575-592. http://doi.org/10.3386/w1393

Ogbulu, O., \& Emeni, F. (2012). Capital Structure and Firm Value: Empirical Evidence from Nigeria. International Journal of Business and Social Science, 3(19), 252-261. Retrieved from www.ijbssnet.com

Pandey, I. M. (2005). What Drives the Shareholder Value?. Asian Academy of Management Journal of Accounting and Finance, 1, 105-120. Retrieved from http://web.usm.my/journal/aamjaf/vol1/1-6.pdf

Purwohandoko. (2017). The Influence of Firm'sSize, Growth, and Profitability on Firm Value with Capital Structure as the Mediator: A Study on the Agricultural Firms Listed in the Indonesian Stock Exchange. International Journal of Economics and Finance, 9(8), 103-110. https://doi.org/10.5539/ijef.v9n8p103

Rehman, A., \& Takumi, H. (2012). Determinants of Dividend Payout Ratio: Evidence From Karachi Stock Exchange (KSE). Journal of Contemporary Issues in Business Research, 1(1), 20-27. Retrieved from https://jcibr.webs.com

Santu, C. D. (2018). Impact of Profitability on Capital Structure: An Analytical Study. International Journal of Trend in Scientific Research and Development, 2(4), 1354-1360. https://doi.org/10.31142/ijtsrd14265

Sobel, M. E. (1982). Asymptotic Confidence Intervals for Indirect Effects in Structural Equation Models. Sociological Methodology, 13, 290-312. https://doi.org/10.2307/270723

Tamrin, M., Rahman, H., Sudirma, M., \& Arfah, A. (2017). Effect of profitability and dividend policy on corporate governance and firm value: Evidence from the Indonesian manufacturing Sectors. Journal of Business and Management, $\quad$ 19(10), $\quad 66-74 . \quad$ Retrieved from http://www.iosrjournals.org/iosr-jbm/papers/Vol19-issue10/Version-8/I1910086674.pdf

Zeitun, R., \&Tian, G. (2007). Capital structure and corporate performance: evidence from Jordan. Australasian Accounting Business and Finance Journal, 1(4), 40-61. http://doi.org/10.14453/aabfj.v1i4.3 